\title{
Possibilities of security measures in museums in the czech republic
}

\author{
Marek Tomastik ${ }^{1, *}$, Katerina Vichova $^{2}$, Eva Hoke $^{1}$ and Erik Pfeffer $^{1}$ \\ ${ }^{1}$ Tomas Bata University in Zlín, Faculty of Logistics and Crisis Management, Studentské nám. 1532, 68601 Uherské Hradiště, Czech \\ Republic \\ ${ }^{2}$ Tomas Bata University in Zlín, Faculty of Applied Informatics, Department of Security Engineering, Nad Stráněmi 4511, 76005 Zlín, \\ Czech Republic
}

\begin{abstract}
The threat of theft of works of art, antiques and books which are always being stolen from museums, galleries and archives in the Czech Republic, as well as abroad, remains present. Given the existence of the current stolen objects markets and the fact that artefacts keep their value which grows in time, theft will continue into the future. Thus, the security of museum collections and buildings is a pressing issue. It is, therefore, important to seek modern, secure and cheap solutions for the smaller museums in the Czech Republic. This paper describes the current state of security in the Czech Republic and proposes appropriate solutions of the problem of security in museums and galleries. The situation is very critical in some museum areas. Historic heritage is not sufficiently protected. The present study solves the analysis of the state of the historical heritage at present. The protection of the historical heritage is better than the Velvet Revolution. The article deals with the protection of monuments currently, analyzes the current security situation in museums in the Czech Republic and suggests a solution that would improve the future security of artefacts. Faculty of Logistics and Crisis Management prepares a workplace to help museums work with risks.
\end{abstract}

\section{Introduction}

Movable cultural heritage exists and always has existed under threat. The most significant threat is its bare material nature. No painting, sculpture or utility object has been created with the intention for it to last forever. Changing and evolving for centuries, the methods of conservation and restoration are, therefore, really only a necessary response to the creators' "imperfection" [8]. Another major threat, probably the most significant one in terms of impact, is fire [12] [20].

Whether it be artwork, historical books or archives, security in museums, archives and libraries for the most part only deals with the protection of collections [17] [19]. The threat of theft of works of art, antiques and books which are always being stolen from museums, galleries and archives in the Czech Republic, as well as abroad, remains present. Given the existence of the current stolen objects markets and the fact that artefacts keep their value which grows in time, theft will continue into the future [23].

It is often true in museum practice that no-one seeks the reasons for securing collections or other cultural objects. For some, they simply are property like any other, only this time of high financial value [9]. The obligation of the manager or owner of a museum collection to provide for its long-term preservation is enshrined in international documents - conventions, guidelines or recommendations, and in the law $[1,2]$. For several decades, the minimum standard of security of cultural heritage has been the focus of, for instance, The International Committee for Museum Security of the International Council of Museums (ICMS, ICOM). However, there has not been success in formulating recommendations of such international standard acceptable to everyone which would determine a minimum level of security for collections and buildings of cultural institutions $[3,5]$. This is due to the fact that any specific solution is always a matter of national legislation.

It is not possible to eliminate natural disasters and no one can reasonably expect to prevent all damage from being avoided. However, a number of measures can be taken to mitigate the effects of devastating natural phenomena and to reduce the risk of damage or loss of other types of emergency situations.

This contribution is an analysis of the complete solution and preparation of manuals for the preparation of an emergency preparedness and response plan, which will be prepared for the needs of museum institutions. The goal is to help you better prepare and respond appropriately to protect our employees, visitors, and collections in an emergency [24]. This process will be very complicated and demanding. The success depends on the staff and management of the museum institutions [25]. Once created, museum artifacts will be protected.

* Corresponding author: mtomastik@utb.cz

(C) The Authors, published by EDP Sciences. This is an open access article distributed under the terms of the Creative Commons Attribution License 4.0 (http://creativecommons.org/licenses/by/4.0/). 
Years of protection, care and investment can be canceled in just a few hours or even minutes. Preparedness is important [18]. Protection plans are important. They help save the heritage.

The aim of this paper is to introduce and develop a knowledge base for the protection of historical heritage in museums in the Czech Republic in order to understand in a sustainable way the risks from the museum's operations as well as the restoration [19]. Protection projects are exposed to a number of risks and are considered unfavourable [15]. It is expected that a research study will generate interest and debate between the professional and research community in the field of cultural heritage renewal for the formal application of the theories and practices of management of the protection of cultural and historical heritage in museums in the Czech Republic [13] [17].

The research method consists of reviewing published literature and analysing the dynamics of the reclamation industry (both from an academic and practical point of view) in order to propose an application framework. Using an inspiring from the basics of building management, the proposed framework seeks to methodically apply risk management in the proposed stages [14].

The aim of the article is to provide risk identification staff to museum workers dealing with risk mitigation measures and preparedness for cultural heritage against disasters with practical tools [12]. The recommended method assumes, in the context of increased risk, the strengthening of the risk assessment process to identify more appropriate risk reduction strategies in the decision-making process.

The article is an Introduction where the bases are worked out. The following is a part of Ways of Compound Compromisations describing the theft in the Czech Republic, Case Study, Discuse where the results are evaluated and eventually everything is evaluated by Conclution.

\section{Ways of Compound Compromisations}

One of the most important threats is theft. The development in the area of theft in the Czech Republic after the Velvet Revolution of 1989 was menacing. Unfortunately, the opening of borders has helped and accelerated and almost uncontrolled movement of cultural objects, mostly stolen ones. For details, see the contingency table of burglaries.

Table 1. Number of burglaries in cultural institutions in years $1988-1997$ [Police of the Czech Republic].

\begin{tabular}{|c|c|c|c|c|}
\hline Years & $\begin{array}{c}\text { Detected } \\
\text { burglary }\end{array}$ & $\begin{array}{c}\text { Clarified the } \\
\text { burglary }\end{array}$ & $\begin{array}{c}\text { In } \\
\text { order of } \\
\text { thousands } \\
\text { of Czech } \\
\text { Crowns }\end{array}$ & $\begin{array}{c}\text { Later } \\
\text { clarified }\end{array}$ \\
\hline 1988 & 42 & 17 & 8685 & 4 \\
\hline 1989 & 51 & 26 & 2192 & 1 \\
\hline 1990 & 611 & 128 & 63105 & 0 \\
\hline 1991 & 996 & 283 & 156117 & 54 \\
\hline
\end{tabular}

\begin{tabular}{|c|c|c|c|c|}
\hline 1992 & 736 & 167 & 35251 & 37 \\
\hline 1993 & 843 & 198 & 124814 & 29 \\
\hline 1994 & 607 & 156 & 54641 & 22 \\
\hline 1995 & 439 & 114 & 51720 & 9 \\
\hline 1996 & 382 & 91 & 31762 & 4 \\
\hline 1997 & 346 & 59 & 36565 & 13 \\
\hline
\end{tabular}

Unfortunately, the opening of borders has helped and accelerated and almost uncontrolled movement of cultural objects, mostly stolen ones. In the Czech Republic, burglaries were the most significant threat to movable cultural heritage mainly in the 1990s. This threat to collections of movables and to preservation funds, while already smaller, still remains among the major ones. These crimes were particularly realized as burglaries. The following table shows the number of burglaries in the years $1998-2016$.

Table 2. Burglaries into compounds housing antique items [Police of the Czech Republic].

\begin{tabular}{|c|c|c|}
\hline Years & $\begin{array}{c}\text { Detected } \\
\text { burglary }\end{array}$ & $\begin{array}{c}\text { Clarified } \\
\text { burglary }\end{array}$ \\
\hline 1998 & 337 & 61 \\
\hline 1999 & 422 & 167 \\
\hline 2000 & 306 & 92 \\
\hline 2001 & 192 & 48 \\
\hline 2002 & 209 & 33 \\
\hline 2003 & 193 & 43 \\
\hline 2004 & 154 & 51 \\
\hline 2005 & 112 & 35 \\
\hline 2006 & 93 & 23 \\
\hline 2007 & 81 & 22 \\
\hline 2008 & 72 & 18 \\
\hline 2009 & 84 & 16 \\
\hline 2010 & 87 & 19 \\
\hline 2011 & 99 & 24 \\
\hline 2012 & 123 & 35 \\
\hline 2013 & 95 & 41 \\
\hline 2014 & 94 & 39 \\
\hline 2015 & 89 & 28 \\
\hline
\end{tabular}

These burglaries have caused great loss in the cultural heritage of the Czech Republic. Therefore, as a response to this negative trend, the Ministry of Culture of the Czech Republic adopted by Resolution No. 307 the document "A Set of Measures for the Reduction of the Critical Situation of the Protection of Collections, Exhibitions and Depositories, Museums, Galleries and Historical Monuments in the Czech Republic" on August 28, 1991 [11]. With this document, the funding of cultural institutions from the state budget increased and these institutions began to buy all sorts of alarm systems, security and emergency systems, fire alarm systems, closed circuit television (CCTV), mechanical safety devices, etc. However, especially in recent years, the support to this program by the Ministry of Culture has been declining and the grant funds can now only satisfy a very limited circle of applicants. The founders of museums and galleries must use their own resources to build at least a basic security infrastructure of their cultural objects keeping institutions. The means to protect cultural heritage are still insufficient. The state 
has thus been gradually losing its role as an arbitrator in the security of movable cultural heritage. This situation is exactly opposite in comparison with other European countries.

At the same time, it cannot be said that the legislation of the Czech Republic would fall behind European legislation. The legislation of the Czech Republic determines exactly what should be done to secure the cultural heritage. It is necessary to mention the following recommendations of the legislation which need to be implemented. $[6,7,8]$

Legislation imposes:

- Continuous processing of risk analysis for the purpose of protecting cultural heritage against illegal acts so that both the probability of occurrence of threats and their impact on the museum and its collection funds themselves are assessed.

- Setting up a work group to address security issues with the participation of specialists from the area of security, incl. collaborating organizations (police, fire brigade).

- Defining an effective security policy for cultural institutions, including prevention and protection plans and plans for dealing with emergencies and disasters.

- Building security systems for cultural institutions according to the prevention and protection plans by implementing effective means of protection, their introduction into service and periodic inspection.

- Regular drills of managing emergencies and disasters, and ensuring training of all workers of cultural institutions and other stakeholders.

It follows from the above that the manager or owner of the collection is required to ensure the preservation of collection items in premises secured by mechanical or electronic protective systems, or a combination of both, and to establish a regime for the entry of external persons, and/or keep the premises under constant surveillance. Furthermore, they are required to ensure the security of collection items during manipulation with collection items and during their transfers.

The Ministry of Culture recommends both that risk analysis be performed, in particular in the areas of theft and fire, and that plans be made for response measures of immediate but also long-term nature. The following measures are recommended to protect the collection items from theft and fire: regulations and directives of organization, guard and surveillance service on duty, mechanical barriers, electronic security systems, closed circuit television - CCTV, electronic access. [6, 7]

This combination provides the level of security to protect the organization from theft. The minimum level of security represents the most basic level of protection. The emphasis on risk analysis is large, as without previous analysis, the construction or modernization of security systems does not make sense. Each such security analysis must be performed uniquely for every organization [9]. It also needs to meet the technical standards of the level of protection from theft, fire or other hazards.

\section{Case Study}

To meet legal obligations, a number of measures need to be taken. The protection of museum compounds is a coherent set of organizational measures and technical means where security systems of protection from theft are in the forefront. The design and evaluation of technical solutions of security systems of a compound against theft and fire has to issue especially from a security assessment of the compound.

The most common ways institutions make mistakes lie in mode of management, set-up of processes, system of physical protection and technical security.

The latest way of security management abroad is represented by integrated safety management systems that include:

- security alarm and emergency system

- electronic access control

- closed circuit CCTV system

- means of mechanical barrier.

To this end, special computer security software has been created or adapted to create comprehensive protection of collections with individual systems. Unfortunately, only the Museum of Decorative Arts in Prague operates on the basis in the Czech Republic, having a very modern sophisticated system capable of evaluating threats and informing authorized personnel to begin taking crisis measures. The system is very modern, designed specifically for the needs of the Museum of Decorative Arts and it is controlled from a single central protection panel. The software evaluates current threats on its own. It is connected to the depository, which it watches, monitoring the manipulation with collection, items especially in the depository, but also in the museum buildings. The identity of individuals is examined using personal identification PIN code, an identity card or a chip, by biometric means or by combinations of the above.

The system is integrated into a single graphical environment for unified use and management. Using this system, individual systems can be operated using a single user interface, but mainly, it creates mutual communication links between the systems. The entire system then combines the features of the compound into a smart, interconnected whole.

The data from technologies are brought into the system into the Communication interface which processes a communication protocol of the technology and enters the data into the database of the Communication interface. This allows communication in the opposite direction, enabling the operator can send commands to individual technologies.

The system ensures automatic coordination of activities across individual technologies in predefined situations. This cooperation takes place entirely 
automatically, according to pre-programmed algorithms while allowing the operator to always have the option to manually enter the solution process by inserting instructions. The interconnection of technologies and monitoring of critical points by CCTV increases the efficiency of the evaluation of alarm information. All compounds may be displayed on a screen based on their geographical location in the map coordinates systems. At the same time, detailed documentation of the compound can also be displayed (photos, ground plans, etc.), including the current status of the observed elements and technological factors. Furthermore, the operating staff are provided with information on the arrival of an alarm event, graphic plans of compound compromisation as the sensor lights light up with a colour matching the compromisation, basic information about the compound or its part, the appropriate courses of action and instructions about the history of the action. The software is very important in performing the so-called key management when the software monitors and manages a comprehensive key agenda - inter alia, the history of the movement of the keys and locks, i.e. who and when had lent a key and who had access to which part of the compound during the course of the emergency situation solution where the program allows to define a narrow range of persons suspected of illegal activities.

The system allows the creation of a hierarchical structure of the monitoring client workplaces:

- client workplace of a museum building

- client workplace of a group of compounds

- client workplace of intervention unit.

\section{Discusion}

Most museums in the Czech Republic cannot afford the technology mentioned in the case study financially. The institutions seek solutions how to increase the security of the museums even through outsourcing.

There is one more great issue, i.e. depositories and curators who manage collections. There are also theft or destruction of artifacts by the musems' own workers.

In the Czech Republic, a Minimum Standard of the Security of Collection-Building Institutions from Theft and Fire is given in the Methodical Guidelines, however, it seems after a survey of the museums that nearly $2 / 3$ of the museums do not meet this standard. The reason is insufficient funding of the museum by the founder or failure in obtaining subsidies.

The minimum security standard must comply with the most basic requirements for collection protection from plain theft and from burglary. When building museum security systems, we must issue from the basic rules that no collection item may remain unmonitored even for a moment. Furthermore, the so-called critical path rule needs to be fulfilled: The time a perpetrator of criminal activity of any kind leading to the theft, destruction or damage to the item needs must be longer than or at least equal to the time from the moment of detection of such activity for the transfer of information about this activity into the place of the permanent operator, i.e. the central operating centre, its evaluation and intervention of the assigned unit. This can be achieved by an appropriate combination of construction measures, technical measures and organizational measures.

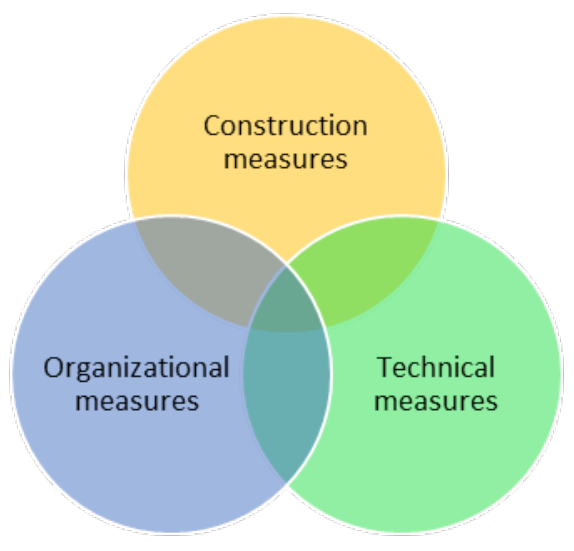

Fig. 1. Anti-theft security concept [author].

The concept of anti-theft protection

- Construction measures - the construction material of the building and its interiors, roofing material, fencing, grids, blinds, doors, windows and other protection of the inner and outer premises.

- Technical measures - alarm distress and security system, closed circuit television, electronic access control, information and communication system.

- Organizational measure - organization of guard and surveillance services, emergency plan, depository regulations, exhibition guest regulations for permanent and temporary exhibitions, directive to the authorisation of entry to the compounds of the organization (outside the exhibition rooms during opening hours), rules of safety signal operation, evacuation plan, operation cards of compounds.

In the spring of 2018, a survey was carried out which the author performed in medium-sized and small museum institutions. The results which have been found show that most museums have sufficient security equipment, but do not have sufficient financial resources for its operation. The security segment is deeply underfunded. The Ministry of Culture has introduced a measure whereby all security equipment must be operated by a single company. This company abuse their monopoly position in relation to national, regional or district museums. A further result of the survey has shown that technical security solutions for museums are known but the non-conceptual security designing reduces the efficiency of these solutions.

The team of the Faculty of Logistics and Crisis Management Tomas Bata University is preparing a Center to help museums in the Czech Republic with risk management. It prepares manuals on how to deal with risk management, improves the security of collections, suggests improving the conservation of artifacts. It prepares a museum colloquium on museum risk management and looks for ways to simplify the issue for 
small museums in cooperation with the Ministry of Culture of the Czech Republic.

\section{Conclusion}

Of course, the higher the security level, the lower the probability of theft of a collection item. However, designing a security system, compromises need to be sought, both for economic reasons, and for staffing reasons, but often times also for reasons of the historical nature of the compound where the collection items are displayed and/or stored. Therefore, the optimal way of security implementation which reflects the financial possibilities of the institution (and not only in terms of investment, but especially regarding operating costs of the system), which is comfortable in terms of the staffing level and the operation of the institution, and the installation of which does not significantly disrupt the aesthetics of the exhibition space. The development of a security system is an ongoing process which requires the engagement of all responsible representatives of all the vocational staff of the (art) museum to reflect their needs, while observing the basic rule - continuous surveillance of all collection items. A proper safety system, then, must be seen as a continuous process of risk analysis, system adjustment and system development planning, and the subsequent implementation of these adjustments. Again and again. Only this way, the cultural institutions can reflect changes in the environment which are brought by both external and internal conditions of its operation.

The Faculty of Logistics and Crisis Management, Tomas Bata University, is implementing projects to create a center to help museums in the Czech Republic, that risk management is well managed and that artifacts are well protected by international and national standards.

This paper was supported by the Development Project of the Organization, Tomas Bata University in Zlín ROV/FLKR/2018/004 and Faculty of Logistics and Crisis Management and by the Integral Grant Agency, Tomas Bata University in Zlín IGA/FLKR/2018/006 and Faculty of Logistics and Crisis Management.

\section{References}

1. R. Drga, D. Janáčová, Recent Researches in Automatic Control. (Montreux, WSEAS Press, 2011)

2. D. Liston, Museum Security and Protection: A Handbook for Cultural Heritage Institutions (Routledge, London, 2015)

3. R. Drga, D. Janáčová, IJERA. 18 (2015)

4. S. Nairne, Art theft and the case of the stolen turners (Reaktion Books, London, 2011)

5. John E. Conklin, Art Crime (Praeger, Westport, Conn., 1994).

6. Recommendation No. 6 of 1996 of the Committee of Ministers of the Council of Europe on the Protection of Cultural Heritage against Illicit Activities.
7. Act No. $122 / 2000$ Coll. on the protection of collections of a museum nature and on the amendment of some other laws.

8. Act No. 20/1987 Coll., On state monument care.

9. N. Charney, Art and crime: exploring the dark side of the art world (Praeger/ABC-CLIO, Santa Barbara, 2009)

10. V. Smejkal, K. Rajs, Řizení rizik ve firmách a jiných organizacich, (Grada, Praha, 2013)

11. Resolution No. 307, 28 August 1991, Ministry of Culture of the Czech Republic. A set of measures to reduce the critical situation of the protection of collections, exhibitions and depositories, museums, galleries and monuments in the Czech Republic.

12. J. Kruliš, Jak vítězit nad riziky: aktivní management rizik - nástroj řízení úspěšných firem. (Linde, Praha, 2013)

13. A. Bernatík. Analýza nebezpečí a rizik Ostrava [online]. Available at: https://www.fbi.vsb.cz/export/sites/fbi/cs/materialy/ AnalyzaRizik.pdf (2016)

14. D. Zolov, Multi Linear Events Sequencing: A Case Study [online]. Available at: http://asasi.org/papers/2011/MES\%20Analysis\%20\%20Dmitri\%20Zotov.pdf (2017)

15. Památky a památková péče, [online]. https://www.npu.cz/cs/npu-a-pamatkovapece/pamatky-a-pamatkova-pece (2017)

16. M. Grasseová, B. Brechta, Efektivní rozhodování: analyzováni, rozhodováni, implementace a hodnoceni. (Edika, Brno, 2013)

17. Risk Management - Techniky posuzování rizik: ČSN EN 31010. Praha: Úřad pro technickou normalizaci, metrologii a státní zkušebnictví (2011)

18. G. D. Lord, B. Lord, The manual of museum management. Second edition. (Lanham, AltaMira Press, a division of Rowman \& Littlefield Publishers, London, Great Britain, 2009)

19.F. Howie, Safety in museums and galleries, (Butterworths, Boston, 1987)

20. T. Merna, F. F. Al-Thani, Risk management: řízení rizika ve firmě. (Computer Press, Brno, 2007)

21. Rizika. Environmentální rizika [online]. Available at: http://www.sci.muni.cz/ herber/other.htm

22. J. Fotr, Jak hodnotit a snižovat podnikatelské riziko, (Management Press, Praha, 2010)

23. T. Stéphane, Securing heritage of religious interest, (UNESCO, France, 2012)

24.C. Menegazzi, Cultural Heritage Disaster Preparedness and Response, (ICOM Paris, France, 2004)

25. V. Dorge, S. L. Jones, Building an Emergency Plan: A Guide for Museums and Other Cultural, Institutions, (the J. Paul Getty Trust, Los Angeles, 1999) 